\title{
Mažesnis depresijos simptomų pasireiškimas tarp uždegiminėmis žarnų ligomis sergančių pacientų, gydomų biologine terapija: kiekybinis palyginamasis pjūvio tyrimas
}

\section{J. Zinkevičiūtè*}

S. Ambrasas*
A. Kiziela**
R. Strumila**
S. Brašiškiené $* * *$
E. Dlugauskas $* * * *$
*Vilniaus universitetas, Medicinos fakultetas

**Vilniaus universitetas, Medicinos fakultetas,

Klinikines medicinos institutas, Psichiatrijos klinika

\section{***Vilniaus universitetas, \\ Medicinos fakultetas, Klinikines} medicinos institutas, Gastroenterologijos, nefrologijos ir chirurgijos klinika,

Hepatologijos, gastroenterologijos ir dietologijos centras

****Vilniaus universitetas,

Medicinos fakultetas,

Klinikines medicinos institutas,

Psichiatrijos klinika;

Vilniaus universiteto ligonine

Santaros klinikos, Neurologijos

centras, Psichiatrijos skyrius
Santrauka. İvadas. Remiantis anksčiau atliktais tyrimais, viena iš galimų depresijos priežasčių yra autoimuninis uždegimas, sukeliantis interleukinų bei citokinų kiekio padidèjimą ir taip paveikiantis bendrą savijautą ir nuotaiką.

Darbo tikslas. Palyginti pacientų, sergančių uždegiminėmis žarnų ligomis ir gaunančių gydymą tumoro nekrozės faktoriaus alfa inhibitoriumi (adalimumabu ar infliksimabu), depresijos ir nerimo simptomus su gydymą kitais vaistais gaunančiais pacientais.

Metodai. Naudotas kiekybinis pjūvio tyrimo dizainas. Taikyti instrumentai: opinio kolito aktyvumo indeksas, Krono ligos aktyvumo indeksas, Beko depresijos klausimyno I neurovegetacinių depresijos požymių poskalè, Hospitalinės nerimo ir depresijos skalė (HADS). İtraukti aktyviu opiniu kolitu arba Krono liga sergantys, antidepresantų nevartojantys pacientai. Dalyviai, gaunantys biologinę terapiją, sudarẻ tiriamąją (eksperimentinę), negaunantys - biologinès terapijos kontrolinę grupę.

Rezultatai. Tyrime analizuoti 46 pacientų duomenys. Tarp grupès, kuri gavo TNF- $\alpha$ inhibitorių, ir grupės, gavusios gydymą kitais vaistais, ligos aktyvumo indeksas reikšmingai nesiskyre (Krono liga - 3,54 vs 4,20; opinis kolitas - 5,70 vs 5,00; $p>0,05$ ). Beko depresijos klausimyno I neurovegetaciniu depresijos požymiu poskalès rezultatai tarp minètu grupiu statistiškai reikšmingai nesiskyrè $(2,52$ vs 3,$91 ; p>0,05)$. HADS bendro ịverčio vidurkis statistiškai reikšmingai didesnis kontrolinėje grupëje $(5,22$ vs 8,$13 ; \mathrm{p}<0,05)$. Lyginant HADS nerimo poskalès vidurkius, skirtumai nebuvo reikšmingi $(3,78$ vs 5,$48 ; p>0,05)$, tačiau HADS depresijos poskalès vidurkis statistiškai reikšmingai didesnis kontrolinëje grupeje $(1,43$ vs 2,$65 ; \mathrm{p}<0,05)$.

Išvados. Tumoro nekrozès faktoriaus alfa inhibitoriumi gydomi pacientai patyrè mažiau depresijos simptomų, esant panašiam ligos aktyvumui, nei pacientai, gaunantys kitą gydymą. Nustatyta, kad tarp pacientų, sergančių uždegiminėmis žarnų ligomis, depresijos simptomai paveikiami labiau negu nerimo simptomai.

Raktažodžiai: tumoro nekrozès faktoriaus alfa inhibitorius, autoimuninė depresija, uždegiminès žarnyno ligos.

\section{Adresas:}

Juta Zinkevičiūtè

Vilniaus universitetas, Medicinos fakultetas

M. K. Čiurlionio g. 21, LT-03101 Vilnius

El.paštas juta.zinkeviciute@gmail.com

\section{IVADAS}

Remiantis Pasaulio sveikatos organizacijos (PSO) duomenimis, depresija yra vienas dažniausių psichikos sutrikimų, dèl kurio kasmet kenčia daugiau nei 300 milijonu

(C) Neurologijos seminarai, 2019. Open Access. This article is distributed under the terms of the Creative Commons Attribution 4.0 International License CC-BY 4.0 (http://creativecommons.org/licenses/by/4.0/), which permits unrestricted use, distribution, and reproduction in any medium, provided you give appropriate credit to the original author(s) and the source, provide a link to the Creative Commons license, and indicate if changes were made. 
žmonių. PSO teigimu, depresija - pagrindinė negalios ir ligų naštos priežastis visame pasaulyje, t. y. šis susirgimas mažina darbingumą ir motyvaciją, sutrikdo tarpasmeninius santykius, apriboja kasdienę veiklą ir kitaip blogina gyvenimo kokybę. Kraštutinė galima depresijos pasekmé - savižudybė [1]. Depresijos sutrikimo patogenezė iki šiol nèra tiksliai žinoma. Šiuo metu mokslinẻje literatūroje pateikiamos kelios pagrindinès galimos depresijos (angl. major depressive disorder) priežastys.

Neurobiologiniai, psichologiniai, socialiniai ir aplinkos faktoriai. Viena svarbiausių depresijos patogenezès teorijų - monoaminų (noradrenalino, serotonino, dopamino) trūkumo sinaptiniame tarpe hipotezè. Iš monoaminų trūkumo teorijos kilo neuroplastiškumo hipotezė, kuri teigia, kad streso metu išsiskiriantys dideli kortizolio ir glutamato kiekiai lemia esminès smegenų adaptacijos funkcijos - neuroplastiškumo, sutrikimą ir taip sudaromos sąlygos psichiatriniam sutrikimui vystytis [2].

Kai kurių autorių teigimu, psichologiniai faktoriai taip pat yra svarbūs depresijos pasireiškimui. Psichologinių veiksnių svarba pabréžiama psichoanalitinėje Z. Froido (1917), kognityvinejje, tarpasmeninių santykių ir socialinių ritmų teorijoje [3-6].

Manoma, kad depresijos pasireiškimui įtakos gali turèti ir psichosocialinis stresas, inicijuojantis adaptacijos procesų pokyčius smegenyse [7]. Šiuo metu laikomasi nuomonės, kad negatyvūs gyvenimo įvykiai ir patirtys yra biopsichosocialinis depresijos patogenezès rizikos faktorius, veikiantis per įvairius biologinius mechanizmu [8].

Imuninès sistemos sutrikimai. Vis labiau tiriama imuninè depresijos teorija, pagal kurią depresijai išsivystyti yra svarbūs imuninès sistemos sutrikimai [9].

Aptikus ryšio tarp stiprios depresijos ir koronarinès širdies ligos įrodymų, pradèta tirti galima imuninès sistemos, ypač uždegiminių citokinų, įtaka depresijai. Remiantis naujausiais ligos patogenezès modeliais, lètinis stresas suaktyvina imuninę sistemą, kuri sukelia uždegimą. Lètinis uždegimas skatina depresijos simptomų pasireiškimą ir inicijuoja patologinius procesus, dèl kurių vystosi širdies ir kraujagyslių ligos. Citokinai - tai signalinès molekulès, reguliuojančios uždegimą reakcijos ị patogenų invaziją metu. Prie jų priskiriami interleukinas $1 \beta$ (IL-1 $\beta$ ), interleukinas 6 (IL-6) ir tumoro nekrozès faktorius alfa (TNF- $\alpha$ ). Citokinai nukreipia leukocitus infekcijos židinio link, skatina juos dalytis ir aktyvinti naikinimo mechanizmus bei atlieka daugybę kitų funkcijų. Šių molekulių, tarp jų ir C reaktyviojo baltymo (CRB), vertès organizme naudojamos kaip uždegiminio atsako indeksas. Svarbu paminėti, kad uždegiminių molekulių poveikis nėra iki galo ištyrinètas.

Esama įrodymų, kad lètinis stresas siejasi su padidèjusiu CRB ir depresijos lygiu. Lètinị stresą patiriančių asmenų organizme nustatomos didesnès IL-6 ir CRB vertès. Dèl ilgalaikių stresorių poveikio gali sustiprèti imuninės sistemos atsakas ị stresą ir sutrikti jos gebejjimas grịžti ị pradinę būseną po stresoriaus nutraukimo. Tai gali lemti pogumburio - hipofizès-antinksčių (PHA) sistemos atsako disreguliacija ir gliukokortikoidų išskyrimas reakcijos ị stresą metu. Uždegiminė reakcija galimai turi įtakos depresijos simptomams ir sukelia vadinamaji „ligonio elgesic“, kuriam būdingi apetito, miego ir socialinès veiklos sutrikimai. Šie procesai gali būti susiję vien su depresija arba pasireikšti tik tiems asmenimis, kuriems depresija vystosi greta kito sveikatos sutrikimo, pavyzdžiui, širdies ir kraujagysliu ligos. Antra vertus, depresija pati gali dalyvauti sukeliant uždegimą. 2009 m. pasirodžiusioje metaanalizèje pateikiami duomenys, palaikantys tris priežastinius modelius: 1) depresija, sukelianti uždegimą; 2) uždegimas, sukeliantis depresiją; 3) procesas, vykstantis lygiagrečiai abiem kryptimis [10].

Šiame tyrime toliau nagrinėjama uždegiminė depresijos teorija, tiriant uždegiminėmis žarnų ligomis sergančius pacientus. Uždegiminemis žarnų ligomis sergančių pacientų organizme kilęs sisteminis uždegimas paveikia ne tik žarnyną, bet ir kitas organų sistemas, tarp jų ir centrinę nervų sistemą. Siekiant prisidèti prie imuninès depresijos kilmės teorijos įrodymų, pagal kurią uždegimas - viena pagrindinių depresijos vystymosi priežasčių, tiriamoji ir kontrolinè grupès sudarytos iš pacientų, sergančių žarnų uždegiminèmis ligomis, kurių organizme kilęs uždegimas galimai sąlygojo ne tik žarnyno ligą, bet ir pokyčius centrinejje nervų sistemoje. Siekėme depresijos ir nerimo psichologinėmis skalėmis nustatyti objektyvizuotų požymių skirtumus tarp uždegiminėmis žarnų ligomis sergančių pacientų, gaunančių gydymą TNF- $\alpha$ inhibitoriais (adalimumabu, infliksimabu), ir pacientų, gaunančių gydymą nuo uždegiminių žarnų ligų kitomis vaistų grupèmis.

\section{TIRIAMIEJI IR METODAI}

\section{Tiriamieji}

Tyrimo populiaciją sudare stacionarizuoti VUL Santaros klinikų Hepatologijos, gastroenterologijos ir dietologijos centro Hepatologijos ir gastroenterologijos skyriaus pacientai bei ambulatoriškai gydomi pacientai, sergantys uždegiminėmis žarnų ligomis. İtraukimo ị tyrimą kriterijai:

- diagnozuotas opinis kolitas arba Krono liga,

- įtraukimo metu taikomas nepertraukiamas gydymas bent 12 savaičių,

- įtraukimo metu nevartoja antidepresantų,

- pakankamai supranta lietuvių kalbą.

Duomenys surinkti apklausiant pacientus ligonineje ir pildant anketas internetu. Atlikti tyrimą $2017 \mathrm{~m}$. spalio 25 d. gautas VUL Santaros kliniku etikos leidimas Nr. 17VR-16278.

Buvo taikytas kiekybinis pjūvio tyrimo dizainas, duomenys rinkti nuo 2017 m. rugsejjo iki 2019 m. kovo mėnesio. Naudoti dalyvių vertinimo instrumentai: opinio kolito aktyvumo indeksas [11], Krono ligos aktyvumo indeksas [12], Beko depresijos klausimyno (BDK) I depresijos neurovegetacinių požymių poskalė [13], Hospitalinė nerimo ir depresijos skalè (HADS) [14]. Depresijos neurovegetaciniams simptomams priskiriamas fizinis nuovargis, motorinis sulètejjimas, miego sutrikimai, apetito ir kūno svorio pokyčiai bei sumažèjęs libido. Stacionarizuoti pacientai 
apklausti ligoninėje, ambulatoriškai besigydantys pacientai pildè identiškas anketas internetu.

Dalyviai suskirstyti ị grupes pagal gaunamą gydymą: tiriamają grupę sudarè TNF- $\alpha$ inhibitorius bei kitus vaistus gaunantys dalyviai, kontrolinę grupę sudarè pacientai, gydomi aminosalicilatais, imunomoduliatoriais, gliukokortikoidais arba minėtų vaistų deriniais, tačiau negaunantys TNF- $\alpha$ inhibitorių.

İ tyrimą ịtraukti 59 pacientai, tačiau dèl trūkstamų duomenų analizuoti 46 pacientai (50,0 \% - moterys, 50,0 \% vyrai), vidutinis amžius - 37,4 m. (nuo $18 \mathrm{iki} 73 \mathrm{~m}$.). Vidutinė uždegiminès žarnų ligos trukmè - $9 \mathrm{~m}$. (nuo 1 iki 31 m.). 23 (50,0 \%) pacientai gavo gydymą TNF- $\alpha$ inhibitoriumi. Tiriamojoje grupeje Krono liga sirgo 13 (56,5\%), opiniu kolitu - 10 (43,5\%). Kontrolinejje grupejje Krono liga sirgo 5 (21,7 \%), opiniu kolitu - 18 (78,3 \%) pacientų. Pacientų charakteristika pateikta 1 lentelèje.

\section{Procedūra}

Dalyviai apie tyrimą buvo informuoti žodžiu ir raštu. Ambulatoriškai besigydantys pacientai apklausti internetu, biologinę terapiją gaunantys pacientai - ligoninėje. Sutikę dalyvauti gavo BDK, HAD, UŽL klausimynus. Dalyvavimas buvo savanoriškas, pacientai atlygio už dalyvavimą tyrime negavo.

\section{Trūkstami duomenys}

Dalyviai buvo pašalinti iš tyrimo, jeigu trūko 3 ir daugiau atsakymų ì klausimus modifikuotame Beko depresijos klausimyne (BDK) ar HAD skalèje arba trūko 2 ir daugiau atsakymų ị klausimus Harvey-Bradshaw klausimyne, ar paprastajame klinikiniame kolito aktyvumo klausimyne. Iš viso ị tyrimą ịtraukti 46 validūs dalyviai.

\section{HAD, BDK, ir kitų klausimynus taškų vertinimas}

Hospitalinė nerimo ir depresijos skalė (angl. The Hospital Anxiety And Depression Scale, HADS) Ivertinti nerimą ir depresinius simptomus naudota 14 klausimų HAD skale, sudaryta A. S. Zigmund ir R. P. Snaith 1983 m. Dabar šis klausimynas patvirtintas ir plačiai taikomas tiriant pacientu patiriamus nerimo ir depresijos simptomus daugelyje šalių. HAD skalè validuota tiriant skirtingas populiacijas, pritaikius klinikinio interviu ar kitus standartizuotus tyrimo metodus [15]. Nors ị lietuvių kalbą HAD skale išversta 1991 m., vis dèlto Lietuvoje ši skalè kol kas nèra validuota [16].

Septyni klausimyno teiginiai yra skirti nerimo, kiti septyni - depresinių simptomų vertinimui. Kiekvienam teiginiui tiriamasis turi pasirinkti vieną jo pastarosios savaitės savijautą geriausiai apibūdinantị atsakymo variantą iš keturių pateiktu ( 0 - simptomo nėra, 3 - stiprus simptomas). Tiek nerimo, tiek depresijos simptomų vertinimo dalyse galima balų suma - nuo 0 iki 21. Abiejų dalių rezultatai sumuojami ir vertinami atskirai: 0-7 balai - nerimo ir depresijos simptomų nėra, 8-10 balų - galima nerimo ir depresinẻ būsena, 11 ir daugiau balų - tikètinas nerimo ir depresi-
1 lentelè. Pacientų charakteristika

\begin{tabular}{||l|c|c||}
\hline & Tiriamoji grupe & Kontrolinė grupé \\
\hline Lytis & & \\
Vyras & $15(65,2 \%)$ & $8(34,8 \%)$ \\
Moteris & $8(34,8 \%)$ & $1565,2 \%)$ \\
\hline Amžius & $39,5 \pm 3,14$ & $34,9 \pm 2,12$ \\
\hline Opinis kolitas & $10(43,5 \%)$ & $18(78,3 \%)$ \\
\hline Krono liga & $13(56,5 \%)$ & $5(21,7 \%)$ \\
\hline $\begin{array}{l}\text { Vidutinè uždegiminės } \\
\text { žarnų ligos trukmė }\end{array}$ & $10 \mathrm{~m}$. & $7 \mathrm{~m}$. \\
\hline
\end{tabular}

jos buvimas [17]. İvairių studijų duomenimis, šios reikšmès tiksliai atspindi tiriamų simptomų buvimą ar nebuvimą [18].

\section{Beko depresijos klausimyno I depresijos neurovegetacinių požymių poskalė (angl. Beck Depression Inventor, BDI)}

Beko depresijos klausimynas I - tai vienas plačiausiai taikomų savęs vertinimo klausimynų depresijos simptomų sunkumui tirti. Skalès validumas ir stabilumas buvo įrodytas įvairių studijų duomenimis $[13,19,20]$. Tyrime naudojama autorių modifikuoto 7 teiginių Beko depresijos klausimyno I depresijos neurovegetacinių požymių poskalè. Klausimynas padeda įvertinti tokius specifinius neurovegetacinius požymius, kaip slopinimas darbe, miego sutrikimai, nuovargis, apetito praradimas, svorio netekimas, somatiniai rūpesčiai ir seksualinis potraukis.

Kiekvienam teiginiui tiriamasis turi priskirti po vieną geriausiai jo savijautą tyrimo momentu atspindintic atsakymą iš keturių pateiktų ( 0 - simptomo nèra, 3 - stiprus simptomas).

\section{Harvey-Bradshaw klausimynas Krono ligos sunkumui ir aktyvumui vertinti}

Harvey-Bradshaw klausimynas sukurtas 1980 m. kaip supaprastinta Krono ligos aktyvumo indekso (angl. Chron's disease activity index, CDAI) versija, vertinanti tik klinikinius parametrus. Tyrime naudotas penkių teiginių klausimynas vertina bendrą savijautą, pilvo skausmo intensyvumą, tuštinimosi skystomis išmatomis dieną dažnị, pilvo padidejjimą ar padidejjusi jautrumą ir komplikacijų buvimą. Kiekvienam teiginiui tiriamasis turi priskirti geriausiai jo savijautą per paskutinius kelis mėnesius atspindintị teiginị ar teiginius arba įrašyti tinkamą atsakymą.

Krono liga sergantiems pacientams, kurių balų suma mažesnè negu 5, tikètina remisija. 5-7 balai - nedidelio aktyvumo liga. 8-16 balų - vidutinio aktyvumo liga. Daugiau kaip 16 - aktyvi (sunki) Krono liga [12].

\section{Paprastasis klinikinis kolito aktyvumo klausimynas} (angl. Simple Clinical Colitis Disease Activity Index) opinio kolito simptomų sunkumui vertinti

Paprastasis klinikinis kolito aktyvumo klausimynas - tai 1988 m. sukurta diagnostinė priemonė opinio kolito aktyvumui vertinti. Tyrime naudotas klausimynas susideda iš šešių teiginių, vertinančių tuštinimosi dažnị dieną, tuštinimosi dažnį naktị, poreikio pasituštinti pobūdị, kraują išma- 
2 lentelè. Tiriamosios ir kontrolinės grupės ligos aktyvumo, Beko ir HADS instrumentų įverčiai

\begin{tabular}{||l|c|c|c||}
\hline & TNF- $\alpha$ inhibitorių grupé & Kito gydymo grupé & p reikšmé \\
\hline Paprastasis klinikinis kolito aktyvumo klausimynas & $5,70 \pm 4,60$ & $5,00 \pm 2,26$ & 0,92 \\
\hline Harwey-Bradshaw klausimynas & $3,54 \pm 2,88$ & $4,20 \pm 3,56$ & 0,65 \\
\hline $\begin{array}{l}\text { Beko depresijos klausimyno I neurovegetacinių depresijos } \\
\text { požymių poskalé }\end{array}$ & $2,52 \pm 2,86$ & $3,91 \pm 2,84$ & 0,10 \\
\hline HAD skale் & $5,22 \pm 4,09$ & $8,13 \pm 4,81$ & $\mathbf{0 , 0 3}$ \\
\hline HADS depresijos poskale் & $1,43 \pm 1,95$ & $2,65 \pm 2,35$ & $\mathbf{0 , 0 5}$ \\
\hline HADS nerimo poskalé & $3,78 \pm 2,71$ & $5,48 \pm 2,98$ & 0,06 \\
\hline
\end{tabular}

3 lentelè. Tiriamosios ir kontrolinės grupės Beko depresijos klausimyno įverčiai

\begin{tabular}{||l|c|c|c||}
\hline & TNF- $\alpha$ inhibitorių grupé & Kito gydymo grupé & p reikšmé \\
\hline 1. Slopinimas darbe & $0,35 \pm 0,71$ & $0,43 \pm 0,66$ & 0,45 \\
\hline 2. Miego sutrikimai & $0,74 \pm 1,01$ & $0,52 \pm 0,88$ & 0,59 \\
\hline 3. Nuovargis & $0,61 \pm 0,72$ & $0,65 \pm 0,57$ & 0,64 \\
\hline 4. Apetito praradimas & $0,04 \pm 0,21$ & $0,43 \pm 0,59$ & $\mathbf{0 , 0 1}$ \\
\hline 5. Svorio netekimas & $0,17 \pm 0,49$ & $0,35 \pm 0,83$ & 0,61 \\
\hline 6. Somatiniai rūpesčiai & $0,39 \pm 0,58$ & $0,65 \pm 0,83$ & 0,30 \\
\hline 7. Sumažėjęs libido & $0,22 \pm 0,67$ & $0,87 \pm 1,06$ & $\mathbf{0 , 0 1}$ \\
\hline
\end{tabular}

tose, bendrą savijautą ir ekstrakolines reakcijas. Kiekvienam teiginiui tiriamasis turèjo priskirti geriausiai jo paskutinių kelių mėnesių būklę atspindintị atsakymą.

Susumavus balus, vertinamas opinio kolito aktyvumas: 0 balų - liga visiškai neaktyvi, 21 balas - maksimalus ligos aktyvumo įvertinimas [11].

\section{Statistinè analizė}

Statistinė analizė atlikta naudojantis „IBM SPSS Statistics 23.0" programa. Kintamuju skirstiniams vertinti naudotas Shapiro-Wilk testas. Vidurkiams su nenormaliais skirstiniais palyginti naudotas Mann-Whitney U testas, pasirinkta statistinio reikšmingumo p reikšmè - mažiau nei 0,05 .

\section{REZULTATAI}

\section{Patikimumas}

Opinio kolito aktyvumo indekso, Krono ligos aktyvumo indekso, Beko depresijos klausimyno neurovegetacinių požymių poskalès, HADS bendro ịverčio, HADS depresijos poskalès ir HADS nerimo poskalès rezultatai neatitiko normaliųjų skirstinių pagal Shapiro-Wilk testą $(\mathrm{p}<0,05)$.

Skalių vidiniam suderinamumui įvertinti naudota Cronbacho $\alpha$. Beko depresijos klausimyno neurovegetacinių depresijos požymių poskalès Cronbacho $\alpha$ rezultatas buvo 0,65 (tiriamojoje grupejje - 0,72, o kontrolinëje $0,57)$. Bendras HAD skalès vidinis suderinamumas - geras (Cronbacho $\alpha-0,80$ ). Vertinant HAD depresijos ir nerimo poskales atskirai, vidinis suderinamumas pagal Cronbacho $\alpha$ atitinkamai lygus 0,70 ir 0,69 .

\section{Palyginimai}

Tarp grupès, kuri gavo TNF- $\alpha$ inhibitorių, ir grupès, kuri gavo gydymą kitais vaistais, ligos aktyvumo indeksas reikšmingai nesiskyrè (Krono liga - 3,54 vs 4,20; opinis kolitas - 5,70 vs 5,00; p >0,05). Beko depresijos klausimyno I neurovegetacinių depresijos požymių poskalès rezultatai tarp minètų grupių statistiškai reikšmingai nesiskyrė $(2,52$ vs 3,$91 ; p>0,05)$. Lyginant HADS bendro įverčio vidurkį, skirtumas tarp grupių buvo statistiškai reikšmingas $(5,22$ vs 8,$13 ; p<0,05)$. Lyginant HADS nerimo poskalès vidurkius, skirtumai nebuvo reikšmingi $(3,78$ vs 5,48 ; $\mathrm{p}>0,05)$, tačiau HADS depresijos poskalès vidurkiai skyrèsi reikšmingai $(1,43$ vs 2,$65 ; \mathrm{p}<0,05)$. Apibendrinti tiriamosios ir kontrolinès grupès ligos aktyvumo, Beko ir HADS instrumentų ịverčiai pateikiami 2 lentelèje. Išsamesnè skalių analizè pateikta 3-5 lentelèse.

\section{DISKUSIJA}

Nepaistant depresijos gydymo pažangos, trečdaliui depresija sergančių pacientų tradicinis gydymas antidepresantais yra neefektyvus [21]. Todèl depresijos etiologiją nagrinėjantys tyrimai tampa pagrindu ieškant naujų gydymo galimybių. Manoma, kad viena iš depresijos rezistentiškumo medikamentiniam gydymui galimų priežasčių - uždegimas.

Šio tyrimo rezultatai atitinka mokslinejje literatūroje skelbiamą informaciją apie galimą uždegiminę depresijos kilmę. 2013 m. Michael Berk ir bendraautorių straipsnyje teigiama, kad depresija yra susijusi su létiniu nedidelio aktyvumo uždegimu, ląstelinio imuniteto aktyvacija ir kompensatorinès priešuždegiminès refleksinès sistemos atsa- 
Mažesnis depresijos simptomų pasireiškimas tarp uždegiminėmis žarnų ligomis sergančių pacientų, gydomų biologine terapija...

4 lentelè. Tiriamosios ir kontrolinės grupès HADS depresijos poskalès įverčiai

\begin{tabular}{||l|c|c|c||}
\hline \hline & TNF- $\alpha$ inhibitoriu grupe & Kito gydymo grupé & p reikšmé \\
\hline 1. „Man linksma“ & $0,22 \pm 0,42$ & $0,61 \pm 0,58$ & $\mathbf{0 , 0 2}$ \\
\hline 2. „Mane ir dabar džiugina tai, kas teikė džiaugsmo anksčiau“ & $0,22 \pm 0,52$ & $0,30 \pm 0,56$ & 0,50 \\
\hline 3. „Iš gyvenimo aš laukiu kažko malonaus“ & $0,17 \pm 0,39$ & $0,30 \pm 0,56$ & 0,44 \\
\hline 4. „Aš jaučiuosi užslopintas ir lètesnių judesių“ & $0,26 \pm 0,45$ & $0,57 \pm 0,51$ & $\mathbf{0 , 0 4}$ \\
\hline 5. „Aš galiu juoktis ir suprasti humorą“ & $0,00 \pm 0,00$ & $0,22 \pm 0,60$ & 0,08 \\
\hline 6. „Man suteikia džiaugsmo gera knyga, radijo arba TV laida“ & $0,39 \pm 0,58$ & $0,30 \pm 0,56$ & 0,55 \\
\hline 7. „Aš nustojau rūpintis savo išvaizda“ & $0,17 \pm 0,65$ & $0,35 \pm 0,65$ & 0,14 \\
\hline
\end{tabular}

5 lentelè. Tiriamosios ir kontrolinès grupès HADS nerimo poskalès įverčiai

\begin{tabular}{||l|c|c|c||}
\hline \hline & TNF- $\alpha$ inhibitorių grupe & Kito gydymo grupé & p reikšmé \\
\hline 1. „Aš jaučiu ịtampą ir nerimą“ & $0,65 \pm 0,57$ & $1,26 \pm 0,92$ & $\mathbf{0 , 0 2}$ \\
\hline 2. „Jaučiu, kad nerimstu vietoje“ & $0,78 \pm 0,74$ & $0,91 \pm 0,60$ & 0,34 \\
\hline 3. „Aš galiu ramiai sėdėti ir atsipalaiduoti“ & $0,39 \pm 0,58$ & $1,00 \pm 0,74$ & $\mathbf{0 , 0 1}$ \\
\hline 4. „Aš jaučiu baimę, lyg kažkas siaubingo turètu atsitikti““ & $0,57 \pm 0,59$ & $0,87 \pm 0,97$ & 0,38 \\
\hline 5. „Mane staiga apima didelis nerimas ir baime““ & $0,43 \pm 0,51$ & $0,57 \pm 0,66$ & 0,59 \\
\hline $\begin{array}{l}\text { 6. „Mane apima baimė, kartu atsiranda vidinis virpulys arba } \\
\text { spaudimas po krūtine“ }\end{array}$ & $0,43 \pm 0,73$ & $0,39 \pm 0,50$ & 0,86 \\
\hline 7. „Mane vargina neramios mintys ir rūpesčiai“ & $0,52 \pm 0,79$ & $0,48 \pm 0,67$ & 0,98 \\
\hline
\end{tabular}

ku. Rezultatų duomenimis, esama koreliacijos tarp uždegimą sąlygojančių veiksnių (pvz., žarnyno mikrobiotos disreguliacijos, nutukimo, rūkymo ir kt.), uždegimo ir depresijos išsivystymo. Uždegimą slopinantys vaistai galètų pagerinti depresijos simptomus [22]. Remiantis tais pačiais metais Charles L. Raison ir Andrew H. Miller atlikto randomizuoto kontroliuojamo tyrimo rezultatais, TNF- $\alpha$ inhibicija nėra veiksminga gydant vaistams rezistentišką depresiją, tačiau gali pagerinti simptomus tiems pacientams, kurių organizme yra padidejusios uždegiminių žymenų vertès [21]. 2015 m. Rebecca Abott ir kolegų sisteminėje apžvalgoje ir metaanalizėje, apėmusioje 2540 lètinėmis ligomis (reumatoidiniu artritu, psoriaze, ankilozuojančiu spondilitu) sergančių pacientų, nurodoma, kad gydymas TNF- $\alpha$ inhibitoriumi, nors ir nedaug, tačiau statistiškai reikšmingai mažina depresijos ir nerimo simptomų pasireiškimą tarp lètinėmis ligomis sergančių pacientų [23]. Vaistams atsparios depresijos ir uždegimo sąsajos bei potencialūs depresijos gydymo metodai, slopinant uždegimą, aptariami ir 2016 m. A. H. Miller ir Ch. L. Raison straipsnyje. Teigiama, kad citokinų ir kitų uždegimo signalinių kelių slopinimas galètų tapti veiksmingu depresijos gydymo metodu [24].

Šio tyrimo duomenimis, uždegimine žarnų liga (opiniu kolitu arba Krono liga) sergantys ir biologine terapija (TNF- $\alpha$ inhibitoriumi infliksimabu arba adalimumabu) gydomi pacientai patyrè mažiau depresijos simptomų, nei sergantieji tokio pat aktyvumo uždegimine žarnų liga, bet gydomi kitais, ne biologinės terapijos vaistais. Tai būtų galima paaiškinti tuo, kad TNF- $\alpha$ inhibitorius slopina uždegimą smegenyse.

Tarp eksperimentinès ir kontrolinės grupès uždegiminės žarnų ligos aktyvumo indeksas statistiškai reikšmingai nesiskyrè. Abiejose grupèse tiriamieji patyrè panašaus sunkumo Krono ligos ar opinio kolito simptomus. Tai svarbu interpretuojant tyrimo rezultatus. Sunkesnių simptomų kamuojami pacientai psichologiškai jaučiasi blogiau, todèl gali patirti daugiau depresijos simptomų, nepriklausomai nuo skiriamo gydymo.

Vienodas uždegiminės žarnų ligos simptomų sunkumas eksperimentineje ir kontrolinejje grupèse prisideda prie objektyvesnès tyrimo rezultatu interpretacijos. Tiek kontrolinėje, tiek tiriamojoje grupèje vidutinè uždegiminès žarnų ligos trukmė buvo panaši $(7 \mathrm{~m}$. ir $10 \mathrm{~m}$. atitinkamai). Ilgesnè ligos trukmė galètų būti siejama su blogesne psichologine būsena. İ tyrimą neịtraukti pacientai, vartojantys psichiką veikiančius vaistus, turinčius teigiamą poveiki depresiniams simptomams, kadangi dèl jų poveikio galejo būti stebimi geresni rezultatai skalèse. Tai neleistų stebèti pilno biologinès terapijos poveikio.

Pateiktais moksliniais duomenimis nesiekiama ịrodyti visų depresinių sutrikimų autoimuninès uždegiminės kilmès. Vis dèlto, tam tikrai depresijų grupei galimas toks papildomas patogenezès mechanizmas. Nepaisant galimų rezultatus iškraipančių veiksnių, tikètina, kad biologinè terapija lemia mažesnị depresijos simptomų pasireiškimą ir tarp gydomų pacientų, sergančių uždegiminėmis žarnų ligomis, ar net mažina riziką susirgti depresija. Yra dvi galimos priežastys, kodèl biologinè terapija gali būti veiksminga depresinių simptomų pasireiškimui ir depresijos rizikai mažinti.

Pirmiausia sisteminis uždegimas yra vienas iš daugelio galimų depresijos etiopatogenezès veiksnių [25]. Citokinai gali patekti ic centrinę nervų sistemą, be to, depresija sergančiu pacientų organizme buvo nustatyti padidėję TNF- $\alpha$ kiekiai [26]. Todèl uždegimo mediatorių, kurių 
kiekis padidèja asmenų, sergančių uždegiminėmis žarnų ligomis ir galimai depresija, organizme, sumažinimas, gydant biologinès terapijos vaistais (šiuo atveju TNF- $\alpha$ inhibitoriumi infliksimabu arba adalimumabu), gali palengvinti depresinius simptomus ir užkirsti kelią tolimesniam depresijos vystymuisi. TNF- $\alpha$ inhibicija gali būti veiksminga dèl inhibicinio poveikio kinureninų metabolizmo keliui. Organizme kilus uždegimui, indukuojamas fermentas indolamino 2,3-dioksigenazè, kuri savo ruožtu aktyvina IL-1, IL-6 ir TNF- $\alpha$. Dèl šios priežasties iš triptofano daugiau sintetinama ne serotonino, o kinureninų kelio tarpinių produktuc - kvinolino (angl. quinolinic acid) ir kinureninių rūgščių (angl. kynurenic acid), kurios veikia NMDA gliutamato receptorius, juos perstimuliuoja ir gali pažeisti galvos smegenų žievę. Taigi, uždegimo aktyvinta indoleamino 2,3-dioksigenazė prie depresijos etiopatogenezès prisideda dvejopai - tiek mažindama serotoninerginès sistemos aktyvumą, tiek neurotoksiškai veikdama per NMDA receptorius [27]. Gydant TNF- $\alpha$ inhibitoriais, blokuojamas kvinolino ir kinurenininès rūgšties susidarymas. Taip galimai dideja serotonino kiekis sinapsiniuose tarpuose, išvengiama NMDA neurotoksiškumo centrinei nervų sistemai ir slopinamas depresinių simptomų pasireiškimas.

Fiziologiniu požiūriu, depresijos nuotaikos ir nerimo simptomai kyla per skirtingas neuromediatorių sistemas nei neurovegetaciniai simptomai. Nuotaiką ir nerimą labiau veikia serotonino, o neurovegetacinius požymius dopamino ir adrenalino neuromediatoriai. Siekiant icvertinti, kokią ịtaką uždegimas turi šiems keliams, taikytini skirtingi klausimynai. HAD skale vertinti depresijos ir nerimo simptomai, tikètinai nulemti serotonino kelio pokyčių. Beko depresijos klausimyno I depresijos neurovegetacinių požymių poskale - neurovegetaciniai simptomai, galimai nulemti dopamino neuromediatorių sistemos sutrikimų. Šio tyrimo metu biologinę terapiją gaunančioje grupejje didžiausias statistiškai reikšmingas skirtumas nustatytas tarp depresijos simptomų lygio. Statistiškai reikšmingo neurovegetacinių simptomų skirtumo tarp abiejų grupių nenustatyta. Galima įtarti, kad TNF- $\alpha$ labiausiai paveikia būtent serotoninerginių neurotransmiterių funkciją [28, 29].

Psichologiniai su uždegiminėmis žarnų ligomis susiję veiksniai taip pat gali skatinti depresiją. Lètinè liga ir jos simptomai (nuolatiniai pilvo skausmai, virškinimo sutrikimai, ligos komplikacijos ir kt.) neigiamai veikia gyvenimo kokybę ir taip galimai lemia depresinių simptomų pasireiškimą bei depresijos progresavimą tarp asmenų, sergančių uždegiminėmis žarnų ligomis. Taigi, pačios uždegiminės ligos simptomų pagerejjimas, gydant biologine terapija, galimai prisideda ir prie sumažèjusios depresijos vystymosi rizikos.

Ivvertinus šio tyrimo rezultatus, kyla klausimas, kodėl biologine terapija gydomiems pacientams sumažejo depresiniai, bet ne nerimo simptomai, nors paprastai psichiatrų praktikoje depresiniai ir nerimo sutrikimai yra komorbidiški. Viena iš galimų priežasčių galètų būti depresijos polimorfiškumas. Depresija - klinikinis sindromas, pasireiškiantis dèl ịvairių priežasčių. Tikètina, kad daugumai pa- cientų, sergančių uždegiminėmis žarnų ligomis, depresiniai simptomai nebuvo tipinès psichiatrinės depresijos, kuri dažniausiai yra komorbidiška su nerimo sutrikimu, išraiška. Šiems pacientams galèjo pasireikšti atipinė (metabolinė) depresija, kuri TLK-10 koduojama F32.8 ir F32.9 kodais, o DSM-5 išskiriama kaip „nespecifinis depresinis sutrikimas su atipiniais bruožais“ (angl. unspecified depressive disorder, with atypical features). Šios depresijos patogenezejje svarbesni yra ne monoaminų ar psichosocialiniai veiksniai, o metabolinių ir imuninių molekulių poveikis smegenims [30, 31].

Mūsų tyrimo duomenys sutampa su klinikinių tyrimų rezultatais, patvirtinančiais, kad pacientus, sergančius kitomis lètinėmis ir gyvenimo kokybę stipriai neigiamai veikiančiomis ligomis, pavyzdžiui, psoriaze ar reumatoidiniu artritu, gydant biologinės terapijos vaistais (etanerceptu, adalimumabu, infliksimabu, ustekinumabu), ne tik efektyviai stabdomas ligos progresavimas, bet ir sumažeja depresijos simptomų [32, 33]. 2010 m. G. R. Langley ir Alexa B. Kimball randomizuoto, dvigubai aklo, placebu kontroliuojamo tyrimo metu nustatè, kad vidutinio sunkumo ar sunkia psoriaze sergantiems pacientams, gaunantiems gydymą biologinės terapijos vaistu ustekinumabu, pagerejo HRQqL (angl. Health Related Quality of Life) skalès icverčiai bei depresijos ir nerimo simptomai. Remiantis $2015 \mathrm{~m}$. P. Fleming ir W. P. Gulliver sisteminès apžvalgos rezultatais, yra statistiškai reikšmingas ryšys tarp depresinių simptomų sumažejimo ir vidutinio sunkumo ar sunkia psoriaze sergančių pacientų gydymo adalimumabu, etanerceptu ir ustekinumabu.

\section{TYRIMO STIPRIOSIOS IR SILPNOSIOS PUSĖS}

Tyrimas turi kelis stiprius aspektus. Buvo fiksuojamas kitu vaistų (pavyzdžiui, antidepresantų) vartojimas (nevartojimas) bei psichiatrinès diagnozės buvimas (nebuvimas) tiriamojoje ir kontrolinėje grupèse. Tai padeda užtikrinti populiacijos homogeniškumą. Be to, tarp kontrolinès ir tiriamosios grupių uždegiminių žarnų ligų aktyvumo indeksas statistiškai reikšmingai nesiskyrè. Tai galima įvardinti kaip dar vieną šio tyrimo stiprybę, nes skirtingas lètinès ligos aktyvumas galètų turèti ịtakos ir skirtingam depresinių simptomų sunkumui.

Šio tyrimo viena silpnujų pusių yra depresijos simptomų nespecifiškumas. Depresijai būdingus simptomus gali sukelti ịvairūs sutrikimai, todèl gana sunku ịvertinti, ar depresijos požymiai yra pirminiai, ar antriniai. Be to, esama galimybės, kad biologine terapija gydomi pacientai efektyviau suvaldo uždegiminės žarnų ligos požymius, todèl jaučiasi geriau. Svarbu ir tai, kad HAD skalè šiuo atveju yra gana ribota. Šio tyrimo metu depresiniai simptomai buvo vertinami HAD skale [14], o depresijos neurovegetaciniai požymiai - Beko depresijos klausimynu I [13]. HAD skalès jautrumas ir specifiškumas, diagnozuojant depresiją, yra apie 0,8, kai ribinė verte, nuo kurios laikoma, kad pacientas serga depresija, yra 8 ir didesnè. Vis dèlto, HAD skalè nèra patvirtinta uždegiminėmis žarnų ligomis ser- 
gančių pacientų depresijai vertinti. Todèl svarbu prisiminti, kad kai kurie šiame tyrime dalyvavusių pacientų atsakymai ị klausimus gali atspindèti tam tikrus Krono ligos ar opinio kolito aspektus, o ne tikrą depresiją.

Nors šio tyrimo metu tiriamosios ir kontrolinės grupès uždegiminių žarnų ligų aktyvumas buvo objektyviai vertinamas Harvey-Bradshaw ir paprastuoju klinikiniu kolito aktyvumo klausimynu [11, 12], o depresiniai simptomai HAD skale [14], vis dèlto uždegimo lygio pacientų organizme objektyvus nustatymas (pavyzdžiui, matuojant CRB kieki kraujo plazmoje) nebuvo atliktas. Tai - kita šio tyrimo silpnybė. Uždegiminių žymenų kiekio nustatymas pacientų organizme padètų tiksliau apibrèžti tyrimo populiaciją, kuriai biologinė terapija galètų būti naudinga. Svarbu prisiminti, kad uždegiminių žymenų kiekis kraujyje, smegenyse ir smegenų skystyje gali reikšmingai skirtis dèl riboto hematoencefalinio barjero pralaidumo baltymams, tarp jų - ir citokinams (išskyrus esant sutrikusiam barjero vientisumui arba aktyvios pernašos per kanalus atvejams) [34]. Vis dèlto, ateityje tikslesniems rezultatams gauti gali būti prasmingas kontrolinès ir biologinę terapiją gaunančiu grupių uždegimo lygio organizme objektyvus ịvertinimas.

\section{IŠVADOS, APIBENDRINIMAS IR ATEITIES PERSPEKTYVOS}

Tumoro nekrozės faktoriaus alfa inhibitoriumi gydomi pacientai patyrè mažiau depresijos simptomų, lyginant su pacientais, sergančiais panašaus sunkumo liga, tačiau gydomais kitais, mažiau specifiniais vaistais. Tai paremia prielaidą, kad tumoro nekrozès faktoriaus alfa padidejjimas gali prisidèti prie depresijos simptomų pasireiškimo, o tumoro nekrozès faktorius alfa inhibitorius - juos slopinti. Nustatyta, kad tarp uždegiminėmis žarnų ligomis sergančių pacientų depresijos simptomai (vertinami HADS depresijos poskale) paveikiami labiau negu nerimo (vertinami HADS nerimo poskale).

Šis tyrimas prisideda prie sisteminio uždegimo ir depresijos etiopatogenezès sąsajas tyrinèjančios literatūros įrodymų, kad sisteminị uždegimą organizme mažinantis gydymas biologinès terapijos vaistais gali būti reikšmingas gydant depresiją, ir prie platesnio pacientų, sergančių uždegiminemis žarnų ligomis, psichologinės būklès suvokimo.

\section{Padèka}

Norètume padėkoti uždegiminėmis žarnų ligomis sergantiems pacientams už dalyvavimą šiame tyrime. Tikimės, kad tyrimo duomenys bus naudingi, kuriant efektyvesnius pacientų, patiriančių depresijos ir nerimo simptomus, gydymo ir priežiūros metodus.

\section{Interesų deklaravimas}

Autoriai interesų konfliktų neturi. Autoriai atsako už šio straipsnio turinị.

\section{Literatūra}

1. World Health Organization. Depression. 2018. https://www.who.int/en/news-room/fact-sheets/detail/ depression

2. Liu B, Liu J, Wang M, Zhang Y, Li L. From serotonin to neuroplasticity: evolvement of theories for major depressive disorder. Front Cell Neurosci 2017; 11: 305. https://doi.org/ 10.3389/fncel.2017.00305

3. Joen SW, Amidfar M, Kim YK. Bio-psycho-social risk factors for depression. In: Major depressive disorder: risk factors, characteristics and treatment options. Nova Science Publishers, Inc., 2017; 71-90.

4. Bar M. A cognitive neuroscience hypothesis of mood and depression. Trends Cogn Sci 2009; 13(11): 456-63. https://doi.org/10.1016/j.tics.2009.08.009

5. Stewart JG, Harkness KL. Testing a revised interpersonal theory of depression using a laboratory measure of excessive reassurance seeking. J Clin Psychol 2017; 73(3): 331-48. https://doi.org/10.1002/jclp.22338

6. Ehlers CL, Kupfer DJ, Frank E, Monk TH. Biological rhythms and depression: the role of zeitgebers and zeitstorers. Depression 1993; 1(6): 285-93. https://doi.org/ 10.1002/depr.3050010602

7. Mitchell P. Severity of stressful life events in first and subsequent episodes of depression: the relevance of depressive subtype. J Affect Disord 2003; 73(3): 245-52. https://doi.org/10.1016/S0165-0327(01)00479-7

8. Kay J, Tasman A. Essentials of psychiatry. West Sussex, England, Hoboken, NJ: Wiley, 2006; 1078. https://doi.org/ 10.1002/0470030992

9. England MJ, Sim LJ, eds. Depression in parents, parenting, and children: opportunities to improve identification, treatment, and prevention. Washington, DC, US: National Academies Press, 2009; 119-73.

10. Howren M, Lamkin D, Suls J. Associations of depression with C-reactive protein, IL-1, and IL-6: a meta-analysis. Psychosom Med 2009; 71(2): 171-86. https://doi.org/ 10.1097/PSY.0b013e3181907c1b

11. Walmsley R, Ayres R, Pounder R, Allan R. A simple clinical colitis activity index. Gut 1998; 43(1): 29-32. https://doi.org/ 10.1136/gut.43.1.29

12. Harvey RF, Bradshaw JM. A simple index of Crohn's-disease activity. Lancet 1980; 315(8167): 514. https://doi.org/ 10.1016/S0140-6736(80)92767-1

13. Beck AT, Beamesderfer A. Assessment of depression: the depression inventory. Modern Trends in Pharmacopsychiatry. Psychological Measurements in Psychopharmacology 1974; 7: 151-69. https://doi.org/10.1159/000395074

14. Zigmond AS, Snaith RP. The hospital anxiety and depression scale. Acta Psychiatr Scand 1983; 67(6): 361-70. https://doi.org/10.1111/j.1600-0447.1983.tb09716.x

15. Bocéréan C, Dupret E. A validation study of the Hospital Anxiety and Depression Scale (HADS) in a large sample of French employees. BMC Psychiatry 2014; 14: 354. https://doi.org/10.1186/s12888-014-0354-0

16. Bunevičius R. HAD skalè - patogus depresijos ir nerimo sutrikimų tyrimo instrumentas. Nervų ir psichikos ligos 2002; 1: 19-20.

17. Snaith RP. The Hospital Anxiety and Depression Scale. Health Qual Life Outcomes 2003; 1: 29. https://doi.org/ 10.1186/1477-7525-1-29

18. Bjelland I, Dahl AA, Haug TT, Neckelmann D. The validity of the Hospital Anxiety and Depression Scale: an updated lit- 
erature review. J Psychosom Res 2002; 52(2): 69-77. https://doi.org/10.1016/S0022-3999(01)00296-3

19. Cavanaugh S, Clark DC, Gibbons RD. Diagnosing depression in the hospitalized medically ill. Psychosomatics 1983; 24(9): 809-15. https://doi.org/10.1016/S00333182(83)73151-8

20. Beck AT, Steer RA, Carbin MG. Psychometric properties of the Beck Depression Inventory: twenty-five years of evaluation. Clinical Psychology Review 1988; 8(1): 77-100. https://doi.org/10.1016/0272-7358(88)90050-5

21. Raison CL, Rutherford RE, Woolwine BJ, Shuo C, Schettler P, Drake DF, et al. A randomized controlled trial of the tumor necrosis factor-alpha antagonist infliximab in treatment resistant depression: role of baseline inflammatory biomarkers. JAMA Psychiatry 2013; 70(1): 31-41. https://doi.org/10.1001/2013.jamapsychiatry.4

22. Berk M, Williams LJ, Jacka FN, O'Neil A, Pasco JA, Moylan S, et al. So depression is an inflammatory disease, but where does the inflammation come from? BMC Med 2013; 11: 200. https://doi.org/10.1186/1741-7015-11-200

23. Abbott R, Dickens $C$, et al. Tumour necrosis factor- $\alpha$ inhibitor therapy in chronic physical illness: a systematic review and meta-analysis of the effect on depression and anxiety. J Psychosom Res 2015; 79(3): 175-84. https://doi.org/ 10.1016/j.jpsychores.2015.04.008

24. Miller AH, Raison CL. The role of inflammation in depression: from evolutionary imperative to modern treatment target. Nat Rev Immunol 2016; 16(1): 22-34. https://doi.org/ 10.1038/nri.2015.5

25. Hayley S, Poulter MO, Merali Z, Anisman H. The pathogenesis of clinical depression: stressor- and cytokineinduced alterations of neuroplasticity. Neuroscience 2005; 135(3): 659-78. https://doi.org/10.1016/j.neuroscience. 2005.03.051

26. Dowlati Y, Herrmann N, Swardfager W, Liu H, Sham L, Reim EK, et al. A meta-analysis of cytokines in major depression. Biol Psychiatry 2010; 67(5): 446-57. https://doi.org/10.1016/j.biopsych.2009.09.033

27. Schwarcz R. The kynurenine pathway of tryptophan degradation as a drug target. Curr Opin Pharmacol 2004; 4(1): 12-7. https://doi.org/10.1016/j.coph.2003.10.006

28. Capuron L, Miller AH. Cytokines and psychopathology: lessons from interferon- $\alpha$. Biol Psychiatry 2004; 56(11): 819-24. https://doi.org/10.1016/j.biopsych. 2004.02.009

29. Shuto H, Kataoka Y, Horikawa T, Fujihara N, Oishi R. Repeated interferon- $\alpha$ administration inhibits dopaminergic neural activity in the mouse brain. Brain Res 1997; 747(2): 348-51. https://doi.org/10.1016/S00068993(96)01371-6

30. Lamers F, de Jonge P, Nolen WA, Smit JH, Zitman FG, Beekman ATF, et al. Identifying depressive subtypes in a large cohort study: results from the Netherlands Study of Depression and Anxiety (NESDA). J Clin Psychiatry 2010; 71(12): 1582-9. https://doi.org/10.4088/JCP.09m05398blu

31. Milaneschi Y, Lamers F, Peyrot WJ, Abdellaoui A, Willemsen G, Hottenga J-J, et al. Polygenic dissection of major depression clinical heterogeneity. Mol Psychiatry 2016; 21(4): 516-22. https://doi.org/10.1038/mp.2015.86

32. Fleming P, Roubille C, Richer V, Starnino T, McCourt C, McFarlane A, et al. Effect of biologics on depressive symptoms in patients with psoriasis: a systematic review. J Eur Acad Dermatol Venereol 2015; 29(6): 1063-70. https://doi.org/10.1111/jdv.12909
33. Langley RG, Feldman SR, Han C, Schenkel B, Szapary P, Hsu M-C, et al. Ustekinumab significantly improves symptoms of anxiety, depression, and skin-related quality of life in patients with moderate-to-severe psoriasis: results from a randomized, double-blind, placebo-controlled phase III trial. J Am Acad Dermatol 2010; 63(3): 457-65. https://doi.org/ 10.1016/j.jaad.2009.09.014

34. Basbaum AI, Jessell T. The perception of pain. In: Kandel ER, Schwartz J, Jessell T, eds. Principles of neural sciences. New York, USA: Appleton and Lange, 2000; 472-91.

\section{J. Zinkevičiūtė, S. Ambrasas, A. Kiziela, R. Strumila, S. Brašiškienė, E. Dlugauskas}

\section{REDUCTION OF DEPRESSIVE SYMPTOMS AMONG PATIENTS WITH INFLAMMATORY BOWEL DISEASE TREATED WITH BIOLOGICAL THERAPY:} A QUANTITATIVE COMPARATIVE INCISION STUDY

\section{Summary}

Introduction. Previous studies suggest that one of the possible reasons of depression is the autoimmune inflammation that causes increased interleukin and cytokines levels and thus affects the mood and well-being.

Aims. To compare depression and anxiety symptoms between the patients with inflammatory bowel disease receiving tumor necrosis factor-alpha (TNF- $\alpha$ ) inhibitor (adalimumab, infliximab) and the patients receiving different medical treatment.

Methods. Quantitative cross-sectional study design was used. Instruments: Ulcerative colitis activity index, Crohn's disease activity index, the subscale of neurovegetative depression symptoms of the Beck depression inventory, and Hospital anxiety and depression scale. Patients diagnosed with active ulcerative colitis or Chron's disease and not using antidepressants were included in the study. Participants were divided into an experimental group (receiving tumor necrosis factor-alpha inhibitors) and control group (receiving treatment with other drugs).

Results. 46 patients' data were analysed. The disease activity index was not significantly different between the experimental group and the control group (Chron's disease 3.54 vs 4.20; ulcerative colitis 5.70 vs $5.00 ; p>0.05$ ). The mean scores of neurovegetative depression symptoms subscale of the Beck depression inventory were not significantly different (2.52 experimental vs 3.91 control; $p>0.05$ ) between both groups. The mean score of the hospital anxiety and depression scale were significantly different between both groups ( 5.22 vs $8.13 ; \mathrm{p}<0.05)$, which indicates less depressive symptoms in the experimental group. The mean anxiety subscale scores were not significantly different ( 3.78 vs $5.48 ; p>0.05$ ), while the mean depressive subscale score was significantly different in the control group (1.43 vs 2.65 ; $\mathrm{p}<0.05$ )

Conclusions. Participants treated with tumor necrosis factor-alpha inhibitor experienced fewer depression symptoms than participants showing similar disease activity, but receiving different medical treatment. Depressive symptoms were affected more than anxiety symptoms in the group of inflammatory bowel disease patients.

Keywords: tumor necrosis factor-alfa inhibitors, autoimmune depression, inflammatory bowel disease.

Gauta:

Priimta spaudai:

20190417 20190712 